\title{
Güncel Optimizasyon Yöntemleri Kullanılarak Rezidüel Gravite Anomalilerinden Parametre Kestirimi
}

\section{Parameter Estimation from Residual Gravity Anomalies Using Actual Optimization Methods}

\section{FiKRET DOĞRU1*}

${ }^{1}$ Dokuz Eylül Üniversitesi Mühendislik Fakültesi Jeofizik Mühendisliği Bölümü, 35160, İzmir

Geliș (received) : 17 Aralık (December) 2014

Kabul (accepted) : 24 Mart (March) 2015

\section{Öz}

Bu çalıșmada, jeofizik modellemede yaygın olarak kullanılan global ve geleneksel yöntemlere ek olarak, yapay sinir ağları yöntemleri yeraltı boșluklarına ait rezidüel gravite anomalisinden parametre kestirimi amacıyla kullanılmıștır. İleri Beslemeli Geri Yayılımlı sinir ağı günümüzde ters çözüm problemlerinde sıklıkla kullanılan bir yöntemdir. Bu yönteme ek olarak bu çalıșmada Illeri Kademeli Geri Yayııımlı ve Doğrusal Olmayan Otoregresif sinir ağı, parametre kestirimi için denenmiș ve sonuçlar karșılaștırılmıștır. Ayrıca global bir yöntem olan Genetik Algoritma ve geleneksel bir yöntem olan Levenberg-Marquardt algoritması ile rezidüel anomaliden derinlik ve yarıçap parametreleri hesaplanmıș ve sonuçlar karșılaștııılmıștır. Hem teorik hem arazi verisi üzerinde bu yöntemler denenmiștir. Kuramsal çalıșmalarda, yeraltı boșluklarını temsil eden yatay silindir modeli kullanılmıștır. Yöntemlerin etkinliği yatay silindir gravite anomalisine gürültü eklenerek sınanmıștır. Hata değerleri incelendiğinde Levenberg-Marquardt algoritması ve doğrusal olmayan otoregresif sinir ağının gürültüden en az etkilenen yöntemler olduğu görülmektedir. Arazi verisi olarak Medford (ABD) alanındaki yeraltı boșluğuna ait rezidüel gravite anomalisi kullanılmıștır. Sonuçlar incelendiğinde ileri beslemeli geri yayılımlı ve doğrusal olmayan otoregresif sinir ağının sondajdan bilinen derinlik değerine en yakın sonucu verdiği görülmektedir. Levenberg-Marquardt algoritması kullanılarak arazi verisinin ters çözümü ile en düșük ortalama karekök hata değeri hesaplanmasına rağmen, hesaplanan derinlik sondajdan bilinen derinlik değerine en uzaktır.

Anahtar Kelimeler: Yapay sinir ağları, genetik algoritma, doğrusal olmayan otoregresif sinir ağı, ileri kademeli geri yayılımlı sinir ağı.

\begin{abstract}
In this study, in addition to the extensively used global and traditional methods in geophysical modeling, artificial neural network methods were used to estimate the parameters of residual gravity anomalies of the underground cavities. Feed Forward Backpropagation neural network is a frequently used method in inversion problems today. In this study, Cascade Forward Backpropagation and the Nonlinear Autoregressive neural network were tried to parameter estimation and the results were compared in addition to this method. Besides; by using the global method, Genetic Algorithm and the traditional method, Levenberg-Marquardt algorithm, the depth of residual anomalies and radius parameters were calculated and the results were compared. These methods were tested on both theoretical and field data. The horizontal cylinder model representing the underground spaces was used in the theoretical model studies. The effectiveness of the methods was tested by adding noise to the horizontal cylinder gravity anomaly. When the error values are analyzed, it is observed that the Levenberg-Marquardt algorithm and the nonlinear autoregressive neural network are the methods that are least affected by the noise. As a field data the residual gravity anomalies of the underground space is used in the Medford (USA) area. When the results are examined it is seen that the feed forward backpropagation and the nonlinear autoregressive neural network give
\end{abstract}

\footnotetext{
* F. Doğru

e-posta: fikret.dogru@deu.edu.tr
} 
the closest results to the depth value that is known from drilling. Even though the lowest root mean square error value was calculated from the inversion of field data using by Levenberg-Marquardt algorithm, computed depth is much more distant comparing with present one which was obtained from drilling.

Keywords: Artificial neural network, genetic algorithm, the nonlinear autoregressive neural network, cascade forward backpropagation neural network.

\section{Giriș}

Gravite verilerinin değerlendirilmesinde amaç, gömülü belirti kaynaklarının fiziksel özelliklerinin yatay ve düșey yönde değișimlerinin belirlenmesidir. Veri yorumlamada en önemli problemlerden biri sonucun tek ve kesin olmamasıdır. Bașka bir deyișle aynı belirtiyi üretebilen sonsuz sayıda model tasarımı yapılabilmektedir (Roy, 1962). Bununla birlikte çok çözümlülük sorununun üstesinden gelmek için gömülü yapının fiziksel ve geometrik parametrelerine yönelik ön bilgilerin olması gerekir (Roy vd., 2000). Gravite belirtilerinin değerlendirilmesi için çeșitli sayısal yöntemler kullanılmaktadır. En küçük kareler yaklașımları (Gupta, 1983; Lines ve Treitel, 1984; Abdelrahman vd., 1991; Salem vd., 2003), Euler dekonvolüsyonu (Thompson, 1982; Reid vd., 1990), sinir ağları (Elawadi vd., 2001; Osman vd., 2007; Hajian, 2004), 3B analitik sinyal genliği (Roest vd., 1992), sürekli dalgacık dönüşümü (Chamoli vd., 2006), gravite tensörünün özvektör analizi (Beiki ve Pedersen, 2010), gravite gradyan tensörünün değișmezleri (Oruç, 2010), çoklu uyarlamalı nöro-bulanık çıkarım sistemleri (Hajian vd., 2011) bu yöntemlere örnek olarak gösterilebilir.

Jeofizik yöntemlerde, çoğunlukla ters çözüm problemi doğrusal olmadığından model parametrelerinin kestirimi için doğrusallaştırılmış yinelemeli yöntemler kullanılır. Bu yöntemlerde gözlenen veri ile hesaplanan veri karșilaștırlIır ve uyumun iyileștirilebilmesi için her yinelemede bașlangıç parametreleri güncellenir. Bu iki veri kümesi arasında daha önce belirlenmiș bir uyum gerçekleșene kadar bu yineleme devam eder. Levenberg-Marquardt gibi türev tabanlı yöntemlerde parametrelerdeki iyileștirme ișleminin bașarısı bașlangıç parametrelerine bağlıdır. Gerçek değerlere çok yakın bașlangıç değeri verildiği halde bazı durumlarda global minimum yerine, lokal minimum veya ıraksama gözlenebilmektedir. Geleneksel yöntemlerdeki bu sorunun üstesinden gelebilmek için çözüm uzayının tamamını tarayan global optimizasyon yöntemleri geliștirilmiștir (Szu ve Hartley 1987; Landa vd.,1989; Basu ve Frazer 1990; Sen ve Stoffa 1991; Vestergaard ve Mosegaard 1991; Dosso ve Oldenburg 1991; Sen ve Stoffa 1992).

Global yöntemler, genel olarak doğadan esinlenilerek ortaya atılmıș, mükemmele yakın biçimde gelișen süreç ve olayların matematiksel uyarlamalarıdır. Holland (1975) tarafından geliștirilen Genetik Algoritma doğada aynı türe ait canlı topluluğun içerisindeki bireylerin yașam ortamına uyumluluklarına dayanır. Ortama uyum sağlayan bireyler hayatta kalıp karakterlerini sonraki nesle aktarabilirken, uyumlu olamayan bireyler ise ölür ve karakter bilgileri gen havuzundan silinir.

Bu çalıșmada, rezidüel gravite anomalisinden derinlik ve yarıçap kestirimi için yapay sinir ağları (YSA) yöntemlerinden İleri Beslemeli Geri Yayılımlı (IBGY), İleri Kademeli Geri Yayılımlı (IKGY) ve Doğrusal Olmayan Otoregresif (DOO) sinir ağları kullanılmıștır. Ayrıca parametre kestiriminde Genetik Algoritma ve Levenberg-Marquardt Algoritması karșılaștııılmıștır. Yöntemlerin etkinliği gürültüsüz ve maksimum genliğin \% 5 ile \% 10'u kadar standart sapmalı rastsal gürültü eklenen veriler üzerinde test edilerek sınanmıștır. Arazi verisi olarak Hajian vd. (2012) tarafından verilen Medford (ABD) boșluk alanına ait rezidüel gravite verisi kullanılmıștır. Arazi verisi ile ilgili çalıșmada yatay silindir modeli kullanılarak teorik veriler hesaplanmıș, yarıçap ve derinlik kestirimi yapılmıștır. Elde edilen derinlik sonucu ile sondajdan bilinen derinlik sonucu karșılaștırılmıștır. YSA içerisindeki üç farklı yöntemin sonuçları öncelikle kendi aralarında ve daha sonra Levenberg-Marquardt ve Genetik Algoritma sonuçları ile karșılaștırılmıștır. 


\section{YAPAY SINIR AĞLARI}

Yapay sinir ağları (YSA)'nın tahmin, kestirim, sınıflandırma ve optimizasyon problemlerinde kullanımı giderek artmaktadır. YSA, elektromanyetik (Poulton vd., 1992; Zhang ve Paulson, 1997) ve sismik (Roth ve Tarantola, 1994; Langer vd., 1996; Calderón-Macías vd., 1998) verilerin ters çözümünde, kuyu logu veri analizinde (Huang vd., 1996), sismik dekonvolüsyonda (Wang ve Mendel, 1992; Calderón-Macías vd., 1997) kullanılmaktadır.

Sinir ağları insan beyninin çalıșma prensibi benzetimi yapılarak geliștirilen bir algoritmadır. İnsan beyninde olduğu gibi sinir ağlarında da hücreler nöronlar içerir ve bu nöronlar kendi aralarında farklı șekillerde birbirlerine bağlanarak ağları oluștururlar. Bu ağlar öğrenme, hafızaya alma ve veriler arasında ilișkiyi ortaya çıkarabilme kapasitesine sahiptir. Matematiksel algılayıcı, McCulloch ve Pitts (1943) tarafından biyolojik nöron davranıșından esinlenerek tasarlanmıștır.

Literatürde, ileri beslemeli sinir ağları, radyal temelli sinir ağları, Hopfield sinir ağları, genel regresyon sinir ağları gibi birçok YSA çeșidi bulunmaktadır. YSA'ların her birinde amaç, mevcut veriyle en iyi çözümlenebilecek ağı tespit edebilmektir (Ho, 2009). Bu çalıșma kapsamında doğrusal olmayan parametre kestirimi için öncelikle İBGY sinir ağı, ardından IKKGY ve DOO sinir ağları kullanılmıștır.

YSA uygulamalarının çoğu; giriș, gizli ve çıkıș olmak üzere en az üç katman gerektirir. Giriș katmanı bağımsız değișkenlerin sayısını, çıkış katmanı ise bağımlı değișkenlerin sayısını içerir. Gizli katman modelin özellik belirleyicisidir. Kullanıcı deneme-yanılma yöntemiyle en uygun gizli katman sayısını ve gizli katmandaki nöron sayısını seçmelidir. IBGY sinir ağının şematik gösterimi Şekil 1'de verilmiștir. Bu gösterimde rezidüel gravite değerleri giriș, yarıçap ve derinlik ise çıkıș değerleri olmaktadır. Bu șematik gösterime ait formül eșitlik (1) ile verilmiștir. Problemin çözümünde tüm girișler düğümlerdeki ağırlıklar ile çarpıldıktan sonra gizli nöronlarda toplanır. Sonrasında, eșik bu toplama eklenir ve transfer fonksiyonu aracılığıyla dönüștürülüp bir sonraki katmana aktarılır. Aynı ișlemler çıkıș değerlerini elde etmek için gizli katman ile çıkıș katmanı arasında tekrarlanır. İleri ișlem çıkıș katmanında sonlandıııırken istenilen çıkış değeri ile ağın çıkış değerleri arasındaki hata değeri hesaplanır. Çıkış katmanındaki hata beklenen çıktılar elde edilinceye kadar giriş katmanına geri yayılır (Günaydın ve Günaydın, 2008). Geri yayılım așamasında tüm ağırıklar hata düzeltme kuralına göre yeniden ayarlanır (Haykin, 1999).

İBGY sinir ağı,

$$
\begin{aligned}
& y_{k}=\tilde{f}\left\{\sum_{j=1}^{m} w_{j k} f\left[\sum_{i=1}^{n}\left(w_{i j} x_{i}+b_{1}\right)+b_{2}\right]\right\}, \\
& k=1,2, \ldots \ldots \ldots . l
\end{aligned}
$$

eșitliği ile verilir. Burada $n$ giriș katmanındaki nöron sayısı, $m$ gizli katmandaki nöron sayısı ve çıkıș katmanındaki nöron sayısıdır. $b_{1}$ ilk katmanın eșik değeri, $b_{2}$ ikinci katmanın eșik değeridir. giriș ve gizli katman arasındaki aktivasyon fonksiyonu, ise gizli katman ile çıkıș katmanı arasındaki aktivasyon fonksiyonudur. Tanjant sigmoid, logaritmik sigmoid ve doğrusal aktivasyon fonksiyonları (Haykin, 1999) en iyi performans elde etmek amacıyla ve için en çok tercih edilen fonksiyonlardır. Șekil 1'deki gizli katman değerleri olmak üzere izleyen bağıntı ile verilebilir:

$$
h_{j}=\left(w_{i j} x_{i}+b_{1}\right), j=1, \ldots, m
$$

Eșitlik (2)'yi eşitlik (1)'de yerine koyduğumuzda çıkış değerlerini veren denklem izleyen șekilde verilebilir:

$$
\begin{aligned}
& y_{k}=\tilde{f}\left\{\sum_{j=1}^{m} w_{j k} h j+b_{2}\right\}, \\
& k=1,2, \ldots \ldots \ldots . l
\end{aligned}
$$

Bu çalıșmada sinir ağında çıkıș olarak yarıçap ve yeraltı boșluğunun derinlik değeri olmak üzere iki parametre istendiğinden eșitlik (3)'teki çıkış katmanındaki nöron sayısı, ikidir. Bu durumda (1) numaralı eșitlik izleyen șekilde ifade edilebilir: 


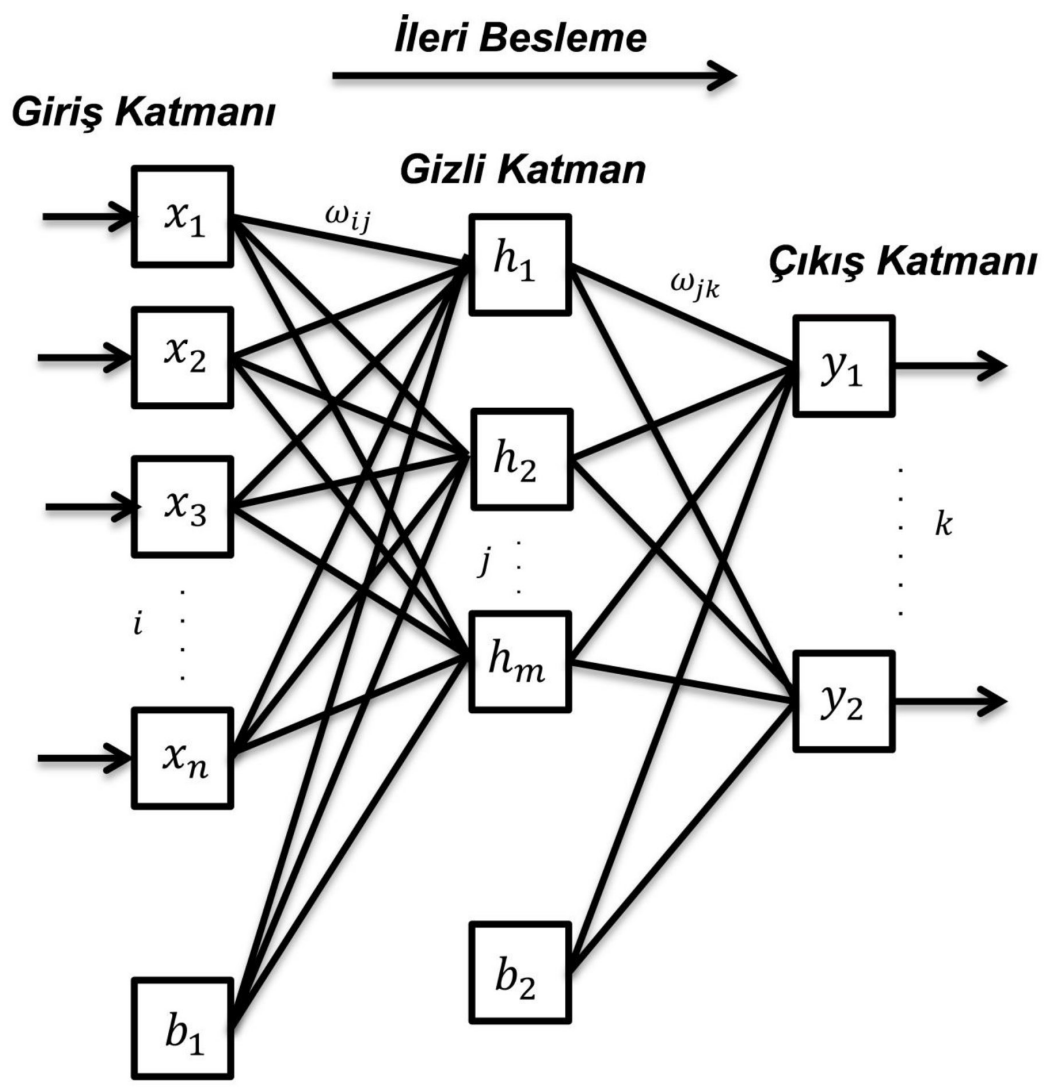

Geri Yayılım

Șekil 1. İleri Beslemeli Geri Yayılımlı sinir ağının șematik gösterimi.

Figure 1. Schematic diagram of an Feed Forward Backpropagation neural network structure.

$$
\begin{aligned}
& R=\tilde{f}\left\{\sum_{j=1}^{m} w_{j 1} f\left[\sum_{i=1}^{n}\left(w_{i j} g_{i}+b_{1}\right)+b_{2}\right]\right\}, \\
& z=\tilde{f}\left\{\sum_{j=1}^{m} w_{j 2} f\left[\sum_{i=1}^{n}\left(w_{i j} g_{i}+b_{1}\right)+b_{2}\right]\right\}
\end{aligned}
$$

Eșitlik (4) ve (5)'te değerleri rezidüel gravite değerleri, $R$ yarıçap ve $z$ derinlik parametreleridir.

Geri yayılım ağı, Rumelhart vd. (1986) tarafından modelin eğitimi için önerilmiștir. Sinir ağında eğitimin anlamı, tüm katmanlarda bulunan nöron bağlantılarındaki ağırlıkların değiștirilerek çıkıș değerlerinin gözlenen değerlere mümkün olduğunca yakın elde edilmesidir. Eğiticili sinir ağında çıkıș değerleri gözlenen değerlere yakınlaștıkça karesel ortalama hata veya global hata yinelemeli olarak azalmaktadır. Global hata fonksiyonu așağıdaki eșitlik ile verilir:

$$
\begin{aligned}
& E=\frac{1}{2 p} \sum_{p=1}^{p} \sum_{k=1}^{1}\left(T_{p k}-y_{p k}\right)^{2}, \\
& p=1,2, \ldots \ldots . P
\end{aligned}
$$

Burada, modelin nöronunun hedef çıkıș değerleridir. ise modelin nöronunun kestirilen çıkıș değerleridir. Eșitlik (6)'da $P$ toplam eğitilen model sayısıdır ve bu çalıșmada 1409 teorik model kullanılarak ağ eğitilmiștir.

İKGY sinir ağı, İBGY sinir ağına benzer șekilde çalıșmaktadır. Bu sinir ağındaki giriș değerleri 


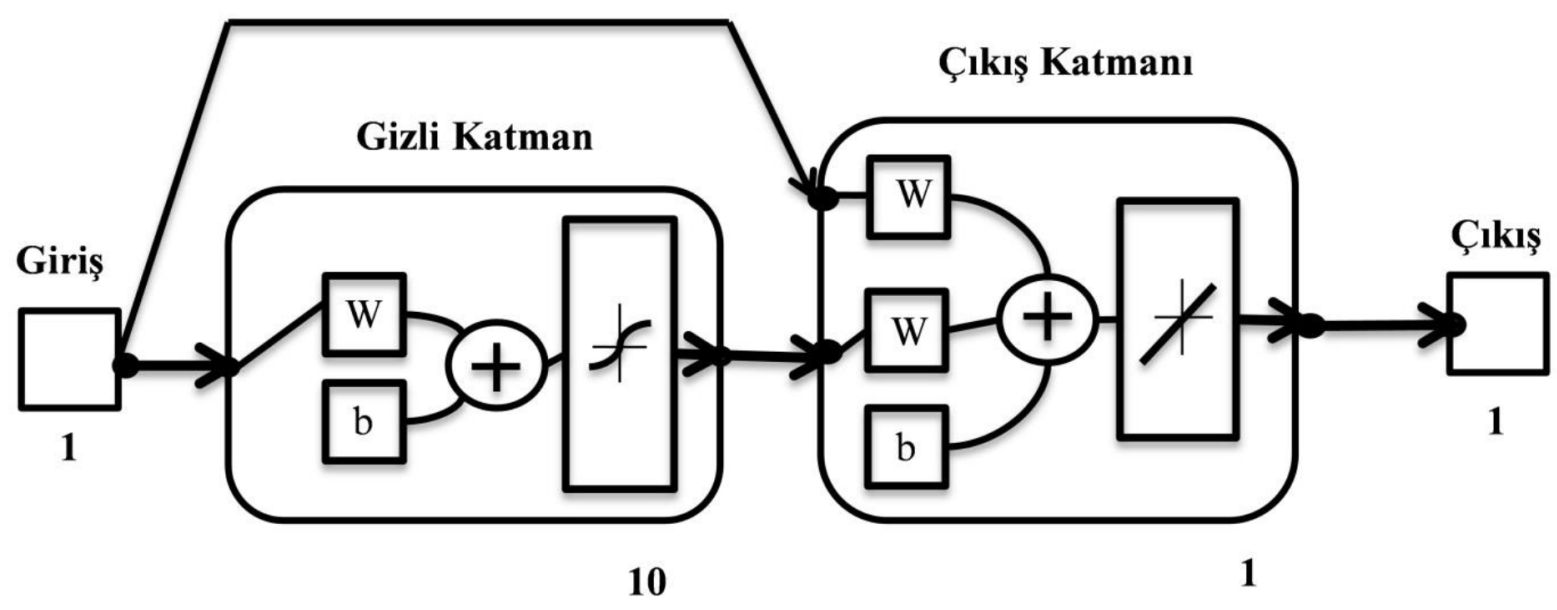

Șekil 2. İleri Kademeli Geri Yayılımlı sinir ağının gösterimi.

Figure 2. Schematic diagram of Cascade Forward Backpropagation neural network.

IBGY'den farklı olarak tüm katmanlarla bağlantııdır. Aynı İBGY'de olduğu gibi İKGY de öğrenme özelliğine sahiptir. İki veya daha fazla katman kullanılarak ve yeterli nöron sayısı seçilmesiyle giriș ile çıkıș arasındaki ilișki sağlanabilir (Şekil 2).

DOO ağında aynı zaman serisindeki geçmiș değerler ve geri beslemeli giriș kullanılarak ağın eğitimi gerçekleștirilir. Bu öğrenme kabiliyeti ile bașka bir zaman serisi için kestirim yapabilmektedir. Bu sinir ağında diğer ağlardan farklı olarak giriș ve geri besleme için gecikme zamanları verilmektedir. Kendi içerisinde de bu ağ farklı türlere ayrılmaktadır (Şekil 3).

\section{GENETIK ALGORITMA}

Genetik algoritma ilk olarak Holland (1975) tarafından geliștirilmiștir. Genetik algoritma, sezgisel bir global optimizasyon metodudur. Yöntem, doğada geçerli olan en iyinin yașaması kuralına dayanarak sürekli iyileșen çözümler üretir.

Genetik algoritmada yeni bireylerin seçilimi yeni ve eskisinden daha iyi toplumların üretilmesi amacıyla yapılmaktadır. Seçilen, yeni yavrular (çözümler) üretecek olan her birey uygunluklarına göre seçilmektedir. Uygunluk fonksiyonu, popülasyondaki her bir elemanın (olası bir çözümün) aranan elemana (doğru çözüme) yakınlığının ölçüsünü verecek șekilde seçilir ve toplumdaki her bireyin ne kadar iyi olduğu gösteren fonksiyondur. Genetik algoritmada amaç, uygunluk fonksiyonunun maksimum yapılmasıdır. Uygunluk fonksiyonunun tersinin alınmasıyla amaç fonksiyonu veya hata fonksiyonu en küçüklenmektedir. Genetik algoritmada seçilim, çaprazlama ve mutasyon operatörleri bulunmaktadır. Bu operatörler bașlangıç popülasyonundan daha iyi uygunluk değerine sahip yeni popülasyonlar elde etmek için kullanılır. Algoritma defalarca popülasyondaki bireylerin çözümünü değiștirerek en iyi sonucu arar. Her adımda popülasyon içerisinden yeni bireyler seçer ve onları bir sonraki jenerasyon için yeni bireyler üretmek üzere çaprazlar. Algoritma jenerasyon sayısının sonlanmasıyla biter. Bu süreç içerisinde en iyi uygunluk değeri çözüm olarak kabul edilir (Luke, 2009; Lee ve Mohamed, 2002).

\section{LEVENBERG-MARQUARDT ALGORITMASI}

Jeofizik problemlerde model parametreleri ile gözlemsel değerler arasındaki ilișki doğrusal olmadığından problem çoğu defa doğrusallaștırılarak çözülür. Doğrusal olmayan denklem sistemleri için genelleștirilmiș en küçük kareler çözümü,

$$
\Delta p=\left(A^{T} A\right)^{-1} A^{T} \Delta d
$$

olarak verilir. 


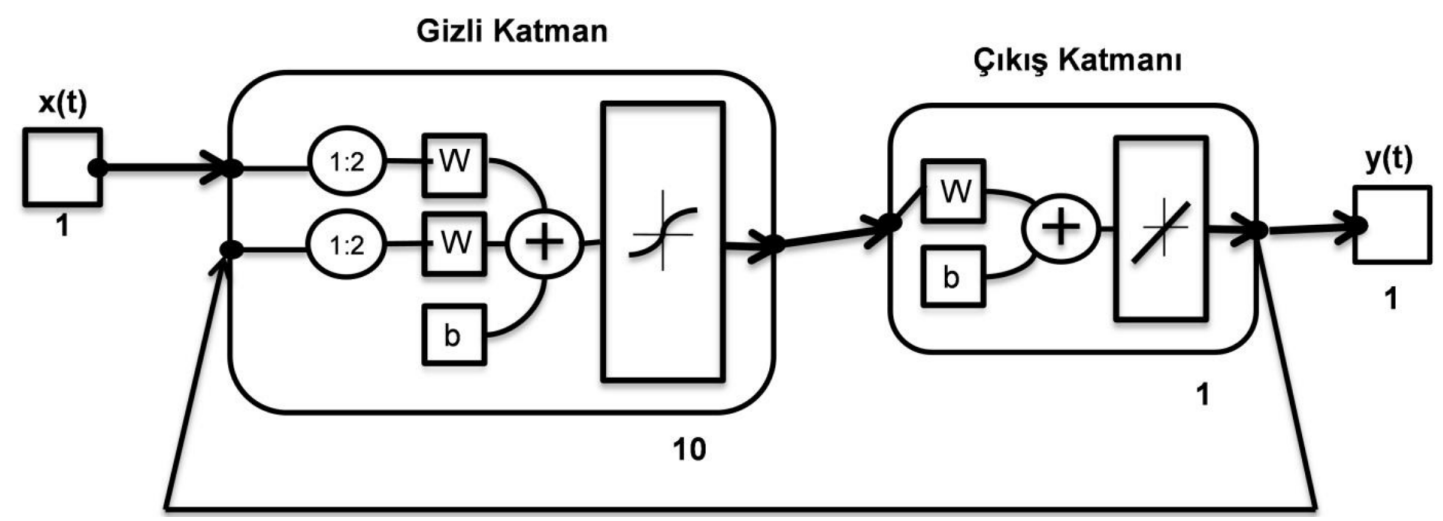

Șekil 3. Doğrusal Olmayan Otoregresif sinir ağının gösterimi.

Figure 3. Schematic diagram of The Nonlinear Autoregressive neural network.

Veri bazı parametrelerin çözümü için tam bilgi içermiyorsa veri ayrımlıık dizeyinin bu parametrelere karșılık gelen sütunları sıfıra yakın olur. Bu parametrelere ait özdeğerler de sıfıra yakın olur. Yineleme sırasında küçük özdeğerlerin neden olduğu salınımların sönümlenmesi gerekir. Eșitlik (7)'de $A^{\top} A$ dizeyinin köșegenlerine dizeyin özelliğine göre seçilen bir sayısal değer eklenerek:

$$
\Delta p=\left(A^{T} A+\varepsilon^{2} I\right)^{-1} A^{T} \Delta d
$$

elde edilir (Lines ve Treitel, 1984). Bu çözüm Levenberg-Marquardt ters çözümü ya da sönümlü en küçük kareler olarak bilinir. Eșitlik (8)'de I birim dizey, $\varepsilon^{2}$ gerçel bir sayı ve sönüm faktörü olarak adlandırılır (Levenberg, 1944; Marquardt, 1963). Sönüm faktörünün alabileceği değerler, sıfır veya göreceli olarak özdeğerlerden büyük bir sayı olabilir. Eğer sönüm faktörü büyük ise, Endik İniș yöntemine benzer șekilde sonuca gidilir. $\varepsilon^{2}=0$ olursa Gauss-Newton yöntemi olarak sonuca ulașilır (Bașokur, 2002; Oruç, 2012).

LM yönteminde sönüm faktörü bașlangıç olarak matrisinin en küçük (özdeğeri) alınmıştır. Sonrasında yinelemeli olarak sönüm faktörü bağıntısı ile güncellenmektedir. Burada ,

$$
\Delta X=\frac{X_{g o z}-X_{h e s}}{X_{g o z}}
$$

olarak verilir (Bașokur, 2002). Eșitlik (9)'da her bir yinelemedeki hesaplanan ile gözlenen arasındaki çakıșmazlık ölçütünün değeridir. Hata,

$$
r m s e=\left(\sqrt{\sum_{i=1}^{n}\left(b_{i}^{g o ̈ z}-b_{i}^{k u r}\right)^{2}}\right)
$$

olarak verilir. Eșitlik (10)'da gözlenen değerler, ise kuramsal rezidüel gravite değerleridir.

\section{Kuramsal Model Çalıșmaları}

Teorik veri olarak, farklı yatay ve düșey konumlardaki 3 adet yatay silindir kullanılarak olușturulan modele ait teorik gravite anomalisi kullanılmıștır. Modelde kullanılan silindirlerin yarıçap değerleri sırasıyla $3 \mathrm{~m}, 4 \mathrm{~m}, 5 \mathrm{~m}$, derinlik değerleri $20 \mathrm{~m}, 25 \mathrm{~m}, 50 \mathrm{~m}$ ve yatay konumları ise sırasıyla -200 ., 50. ve 400 . metrelerdir. Her bir silindir için yoğunluk farkı -1 $\mathrm{gr} / \mathrm{cm}^{3}$ olarak alınmıștır (Şekil $4 \mathrm{a}$ ve b). Ayrıca teorik veriye sırasıyla $\% 5$ ve $\% 10$ gürültü eklenmiștir. Her bir YSA metodunun eğitim așaması tamamlandıktan sonra gürültüsüz, gürültülü teorik veriler ağa girilerek yarıçap ve derinlik değerleri elde edilmiștir. Ağın eğitimi için profil uzunluğu 900 m ve örnekleme aralığı 1'er metre olan 900 adet teorik veri üretilmiştir. YSA yöntemlerinin hepsinde momentum ve uyarlanabilir öğrenme oranlı geri yayılımlı gradyan iniș eğitim fonksiyonu kullanılmıștır. YSA eğitim așamasında öğrenme oranı 0.01 ve momentum katsayısı 0.9 alınmıștır. Tek gizli katman kullanılmıștır ve nöron sayısı 10 

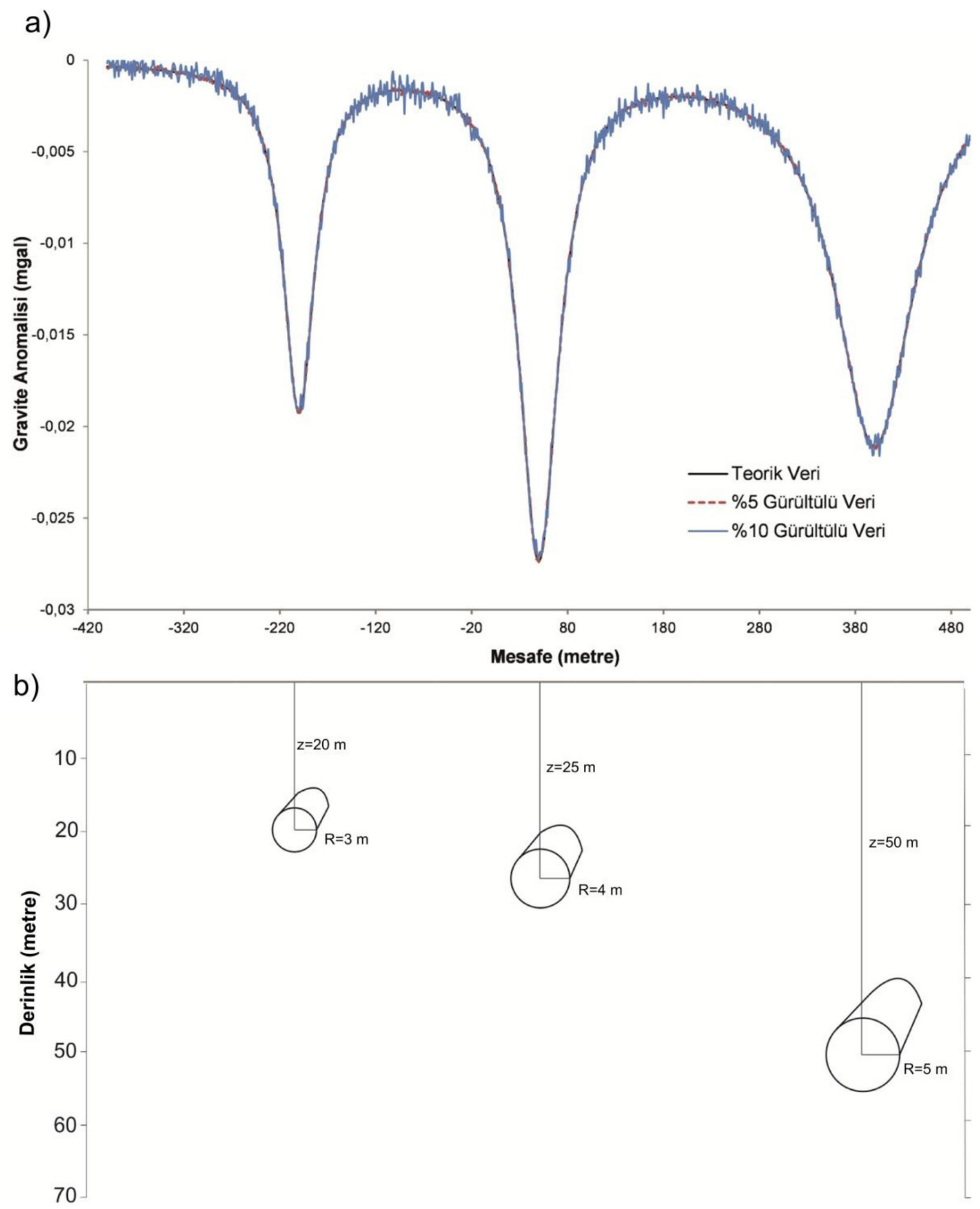

Șekil 4. a) Gürültülü ve gürültüsüz teorik rezidüel gravite anomalileri ve b) Yatay silindir modellerin derinlik kesiti. Figure 4. a) Noise-corrupted and noise-free theoretical residuel gravity anomalies and b) Depth section of the horizontal cylinder models. 
olarak alınmıștır. DOO ağında eğitim așamasında gecikme zamanları $[0,1]$ ve $[1,2]$ olarak varsayılan değer kullanıımıștır. YSA yöntemleri için 10000 yineleme sayısı ağın eğitiminde ortalama karakök hata değerinin sıfıra yaklașmasından dolayı yeterli görülmüștür.

GA'da populasyon ve çaprazlama sayısı 100 olarak belirlenmiștir. Populasyon dıșındaki parametreler varsayılan olarak alınmıștır. Bu parametreler sırasıyla jenerasyon sayısı 100, çaprazlama fonksiyonu dağınık ve yeniden üretim için 0.8 , seçilim fonksiyonu stokastik uniform ve mutasyon fonksiyonu Gaussian fonksiyon alınmıștır. GA, 51 yinelemede yeterli hata değerine ulaștığından algoritma durdurulmuștur.

LM'de ise yineleme sayısı 100 olarak verilmiș ancak yineleme sayısı 6'dan sonra hata veya parametrelerde bir değișim gözlenmemiștir. Bașlangıç değerleri için yarıçap ve derinlik parametreleri her seferinde 10 metre alınmıștır ve ilk olarak 20 yineleme verilmiștir. Ancak sonuçlar gözlemlendiğinde gürültülü ve gürültüsüz teorik veriler için 6 yineleme sayısından sonra parametre ve hata sabit kalmaktadır.

Tüm yöntemler için gürültüsüz teorik verinin ters çözümünden doğru model parametrelerine çok yakın değerler hesaplanmıștır. Gürültülü teorik verilerin ters çözüm sonucu ortalama karakök hata değerlerine bakıldığında, İKGY ağının gürültüye en duyarlı yöntem olduğu gözlenmiștir. GA, DOO sinir ağı ve özellikle LM algoritmasının gürültülü teorik verinin ters çözümü sonuçlarından doğru modele en yakın sonuçları verdiği görülmektedir (Çizelge 1).

Çizelge 1. Gürültülü ve gürültüsüz veri için uygulama sonuçları.

Table 1. The application results for noise-free and noise-corrupted data.

\begin{tabular}{|c|c|c|c|c|c|c|c|c|}
\hline YÖNTEM & $\begin{array}{c}\text { Yarıçap } \\
\text { (m) }\end{array}$ & $\begin{array}{l}\text { Derinlik } \\
\text { (m) }\end{array}$ & $\begin{array}{c}\text { Yarıçap } \\
\text { (m) }\end{array}$ & $\begin{array}{l}\text { Derinlik } \\
\text { (m) }\end{array}$ & $\begin{array}{c}\text { Yarıçap } \\
(\mathrm{m})\end{array}$ & $\begin{array}{l}\text { Derinlik } \\
\text { (m) }\end{array}$ & $\begin{array}{c}\text { Rmse } \\
(\%)\end{array}$ & $\begin{array}{c}\text { Yineleme } \\
\text { Sayısı }\end{array}$ \\
\hline Parametreler & 3 & 20 & 4 & 25 & 5 & 50 & - & - \\
\hline İBGY & 3 & 19,99 & 4 & 24,99 & 4,99 & 50 & 0,073 & 10000 \\
\hline İBGY (\%5) & 3,16 & 20,01 & 3,83 & 24,97 & 4,92 & 49,97 & 1,88 & 10000 \\
\hline İBGY (\%10) & 2,66 & 20,04 & 4,32 & 24,96 & 5,56 & 49,54 & 5,77 & 10000 \\
\hline İKGY & 2,99 & 20 & 3,99 & 24,99 & 4,99 & 49,99 & 0,13 & 10000 \\
\hline İKGY (\%5) & 2,9 & 19,81 & 3,78 & 24,77 & 4,99 & 50,06 & 1,87 & 10000 \\
\hline İKGY (\%10) & 3,4 & 20,36 & 4,73 & 24,85 & 5,93 & 50,35 & 10,7 & 10000 \\
\hline DOO & 2,99 & 20 & 4 & 25 & 4,99 & 50 & 0,1 & 10000 \\
\hline DOO (\%5) & 2,94 & 19,94 & 3,95 & 24,93 & 4,92 & 49,94 & 0,83 & 10000 \\
\hline DOO (\%10) & 2,79 & 19,79 & 3,81 & 24,76 & 4,74 & 49,78 & 2,57 & 10000 \\
\hline GA & 2,99 & 20 & 3,99 & 25 & 4,99 & 50,09 & 0,15 & 51 \\
\hline GA (\%5) & 2,9 & 19,94 & 3,8 & 24,9 & 4,92 & 50,07 & 1,89 & 51 \\
\hline GA (\%10) & 2,78 & 20,86 & 3,8 & 24,93 & 4,74 & 50,07 & 3,07 & 51 \\
\hline LM & 3 & 20 & 4 & 25 & 4,99 & 49,99 & 0,12 & 100 \\
\hline LM (\%5) & 2,99 & 19,97 & 4 & 25 & 4,99 & 49,97 & 0,26 & 100 \\
\hline LM (\%10) & 2,99 & 20,02 & 4 & 25,17 & 4,99 & 49,83 & 1,06 & 100 \\
\hline
\end{tabular}




\section{Arazi Verisi Uygulaması}

Şekil 5'te Amerika'nın Florida eyaletindeki Medford bölgesindeki yeraltı boșluğunun rezidüel gravite anomali eğrisi (Butler, 1984) verilmiștir. Bu bölgedeki yeraltı boșluklarının önceki jeolojik çaIıșmalardan küre veya silindire (yatay veya düșey) yakın bir geometriye sahip olduğu bilinmektedir. Hajian vd., (2012) tarafından yapılan çalıșma sonucunda Medford alanındaki yeraltı boșluğunun șekli yatay silindir olarak belirlenmiștir. Sondajdan elde edilen derinlik değeri ise 3.57 m'dir.

Ağın eğitimi için profil uzunluğu 14 m ve örnekleme aralığı $0.1 \mathrm{~m}$ olan 1409 tane teorik veri kullanılmıștır. Teorik veriler, yatay silindir modeline uygun biçimde ve boșluklar yüzeye yakın olduğundan sığ derinlik değerleri ile üretilmiștir. YSA yöntemlerinin hepsinde momentum ve uyarlanabilir öğrenme oranlı geri yayılımlı gradyan iniș eğitim fonksiyonu kullanılmıștır. YSA eğitim așamasında öğrenme oranı 0.01 ve momentum katsayısı 0.9 alınmıștır. Tek gizli katman kullanılmıștır ve nöron sayısı 10 alınmıștır. DOO ağında eğitim așamasında gecikme zamanları $[0,1]$ ve $[1,2]$ olarak varsayılan değer kullanılmıștır.

Uygulanan YSA yöntemlerinden aynı yineleme sayısında çalışma mekanizmaları çok farklı olmasına rağmen İBGY ve DOO yaklașık olarak aynı sonuçları vermiș olup, bu yöntemlerden sondajdan bilinen derinlik değerine çok yakın değerler elde edilmiștir. Sondajdan bilinen derinlik değeri $3.57 \mathrm{~m}$, IBGYY ve DOO sinir ağlarının ters çözüm sonuçları ise yaklașık olarak 3.52 m'dir. Teorik çalıșmada da olduğu gibi IKGY

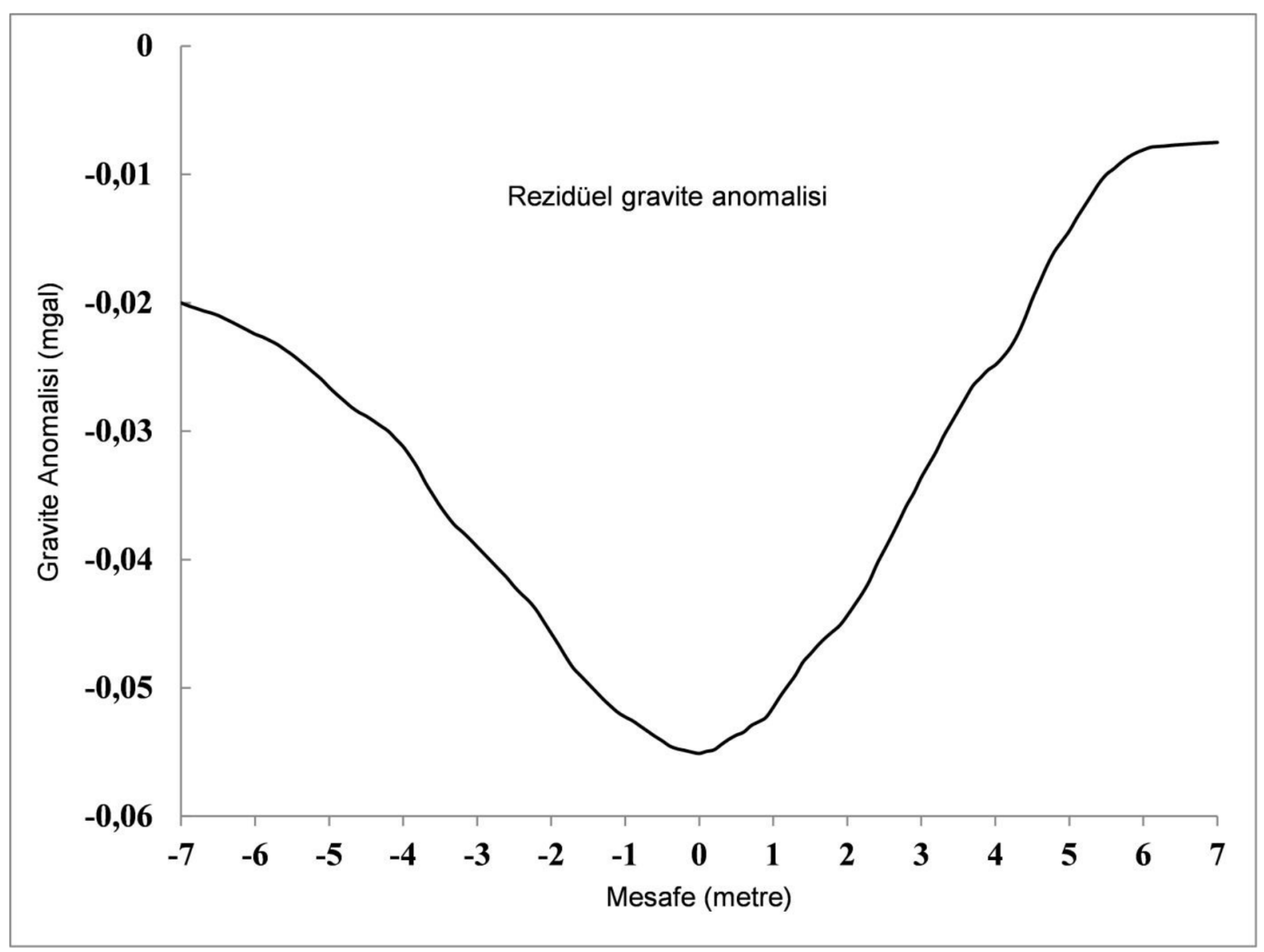

Șekil 5. Medford test sahasındaki boșluğun rezidüel gravite profil eğrisi (Butler, 1984).

Figure 5. Residual gravity profile over a cavity at the Medford test site (Butler, 1984). 
Çizelge 2. Arazi verisi için uygulama sonuçları.

Table 2. The application results for field data.

\begin{tabular}{ccccc}
\hline YÖNTEM & Yarıçap $(\mathbf{m})$ & Derinlik $(\mathbf{m})$ & Rmse $(\%)$ & Yineleme Sayısı \\
\hline IBGY & 1,8504 & 3,5241 & 5,9 & 10000 \\
IKGY & 1,979 & 3,8045 & 8,1 & 10000 \\
DOO & 1,8501 & 3,526 & 5,9 & 10000 \\
GA & 1,829 & 3,656 & 5,4 & 51 \\
LM & 1,851 & 3,8373 & 5,3 & 100 \\
\hline
\end{tabular}

sinir ağında ters çözüm sonucundan \% 8.1 ortalama karekök hata ile en yüksek hata değeri elde edilmiștir.

GA için popülasyon sayısı 100, çaprazlama parametresi ise 0.8 alınmıștır. GA sonucunda elde edilen parametre değerlerine ve \% 5.4 ortalama karekök hata değerine bakıldığında sonucun kabul edilebilir ve derinlik değerinin sondajdan elde edilen derinlik değeri ile yakın olduğu görülmektedir. GA derinlik değerini, İBGY ve DOO sinir ağının sonucuna göre daha yüksek ancak yarıçap değerini ise daha düșük bulmuștur.

LM yönteminde en düșük ortalama karakök değerine ulaștığımız görülmektedir. Bu çalıșmada ek bilgi olarak sondajdan elde edilen derinlik değeriyle daha sağlıklı yorumlama yapılmıștır. Bașlangıç parametreleri yarıçap ve derinlik ters çözüm bașlangıcında 10'ar metre alınmıștır. LM yönteminin en düșük hata vermesine rağmen sondajdan elde edilen derinlik bilgisiyle karșılaștırdığımızda tüm yöntemler arasında derinlik değeri bakımından bilinen sondaj değerine en uzak değeri vermiș olduğu görülmektedir. LM'de 4 yinelemeden sonra hata değerinde daha fazla azalma gözlenmemiștir. Tüm yöntemlerin sonuçları Çizelge 2'de verilmiștir.

\section{SONUÇLAR VE TARTIȘMA}

$\mathrm{Bu}$ çalıșmada rezidüel gravite anomalisinden yarıçap ve derinlik parametre kestirimi için güncel sinir ağları yöntemleri (IKGY, DOO) denenmiștir. Bu yöntemlere ek olarak IBGY sinir ağı, GA ve LM algoritması kullanılmıș ve sonuçlar karșılaștırılmıștır. Yöntemlerin etkinliği; gürültülü, gürültüsüz teorik ve arazi verilerinde denenerek sınanmıștır. Gürültülü ve gürültüsüz teorik verilere yöntemlerin uygulanması sonrasında hata değerleri kabul edilebilir ölçüde düșük elde edilmiștir. GA ve LM yöntemlerine göre eğitim așamasından dolayı YSA yöntemlerinin çok daha fazla hesap zamanı gerektirdiği bu çaIıșmada gözlenmiștir. DOO sinir ağının çalışma prensibi İBGY sinir ağı yönteminden farklı olmasına rağmen ters çözüm sonucu birbirine çok yakın değerler elde edilmiștir. IKKGY sinir ağı hem gürültülü teorik hem arazi uygulamasında en yüksek hata değerlerini veren yöntem olmuștur. LM algoritması ile arazi verisinin ters çözüm sonucu en düșük hata değeri elde edilmesine rağmen sondajdan bilinen derinlik değerine en uzak değer elde edilmiștir. Geleneksel yöntem olan LM veya artık jeofizikte sıkça kullanılan global yöntem olan GA gibi YSA yöntemlerinin de jeofizik problemlerinin ters çözümünde başarılı sonuçlar verdiği görülmüştür. YSA, GA ve LM yöntemlerinin çalıșma prensipleri çok farklı olmasına rağmen aynı problemlere uygulanabilirliği ve jeofizik problemlerin çözümünde DOO ve İKGY ağlarının da, İBGY yöntemine ek olarak kullanılabileceği görülmüștür.

\section{KATKI BELIRTME}

Yazar makaleye değerli, gerekli ve yapıcı eleștirileri ile katkı sağlayan hakemler Doç. Dr. Bülent ORUÇ ve Dr. Muzaffer Özgü ARISOY'a teșekkür eder. 


\section{KAYNAKLAR}

Abdelrahman, E.M., Bayoumi, A.I., ve El-Araby, H.M., 1991. A least-squares minimization approach to invert gravity data, Geophysics, 56, 1, 115-118.

Basu, A., ve Frazer, L.N., 1990. Rapid determination of critical temperature in simulated annealing inversion, Science, 249, 1409-1412.

Bașokur, A.T., 2002. Doğrusal ve Doğrusal OImayan Problemlerin Ters-Çözümü. Jeofizik Mühendisleri Odası Eğitim Yayınları, Ankara.

Beiki, M., ve Pedersen, L.B., 2010. Eigenvector analysis of gravity gradient tensor to locate geologic bodies, Geophysics, 75, 6, I37-149.

Butler, D.K., 1984. Microgravimetric and gravity gradient techniques for detection of subsurface cavities, Geophysics, 49, 7, 1084-1096.

Calderón-Macías, C., Sen, M.K., ve Stoffa, P.L., 1997. Hopfield neural networks, and mean field annealing for seismic deconvolution and multiple attenuation, Geophysics, 62, 3, 992-1002.

Calderón-Macías, C., Sen, M.K. ve Stoffa, P.L., 1998. Automatic NMO correction and velocity estimation by a feedforward neural network, Geophysics, 63, 5, 1696-1707.

Chamoli, A., Srivastava, R.P. ve Dimri, V.P., 2006. Source depth characterization of potential field data of Bay of Bengal by continuous wavelet transform, Indian Journal of Marine Sciences, 35, 3, 195-204.

Dosso, S.E., ve Oldenburg, D.W., 1991. Magnetotelluric appraisal using simulated annealing, Geophysical Journal International, 106, 370-85.

Elawadi, E., Salem, A., ve Ushijima, K., 2001. Detection of cavities and tunnels from gravity data using a neural network, Exploration Geophysics, 32, 4, 204-208.

Gupta, O.P., 1983. A least-squares approach to depth determination from gravity data, Geophysics, 48, 3, 357-360.
Günaydın, K., ve Günaydın, A., 2008. Peak ground acceleration prediction by artificial neural networks for Northwestern Turkey, Mathematical Problems in Engineering, 2008.

Hajian, A., 2004. Depth Estimation of Gravity Anomalies by Neural Network, M.Sc. Thesis, Tehran University, Iran (in Persian).

Hajian, A., Styles, P. ve Zomorrodian, H., 2011. Depth estimation of cavities from microgravity data through multi adaptive neuro fuzzy interference system. In: "Near Surface" 2011, Proc. 17th European Meeting of Environmental and Engineering Geophysics, 12-14 September 2011, Leicester, UK.

Hajian, A., Zomorrodian, H., ve Styles, P., 2012. Simultaneous Estimation of Shape Factor and Depth of Subsurface Cavities from Residual Gravity Anomalies using Feed-Forward Back-Propagation $\mathrm{Ne}$ ural Networks, Acta Geophysica, 60, 1043-1075.

Haykin, S., 1999. Neural Networks: A Comprehensive Foundation, 2nd ed., PrenticeHall Inc., Englewood Cliffs.

Ho, T. L., 2009. 3-D inversion of borehole-tosurface electrical data using a backpropagation neural network, Journal of Applied Geophysics, 68, 4, 489-499.

Holland, J., 1975. Adaptation in Natural and Artificial Systems, University of Michigan Press.

Huang, Z., Shimeld, J., Williamson, M., ve Katsube, J., 1996. Permeability prediction with artificial neural network modeling in the Ventura gas field, offshore eastern Canada, Geophysics, 61, 2, 422436.

Landa, E., Beydoun, W., ve Tarantola, A., 1989. Reference velocity model estimation from prestack waveforms: coherency optimization by simulated annealing, Geophysics, 54, 984-990.

Langer, H., Nunnari G., ve Occhipinti L., 1996. Estimation of seismic waveform governing parameters with neural networks, 
Journal of Geophysical Research, 101, B9, 20109-20118.

Lee, K. Y., ve Mohamed, P. S., 2002. A real-coded genetic algorithm involving a hybrid crossover method for power plant control system design, in Proceedings of the 2002 Congress on Evolutionary Computation, pp. 1069-1074.

Levenberg, K., 1944. A Method for the solution of certain nonlinear problems in least squares. The Quarterly of Applied Mathematics, 2, 164-168.

Lines, L.R. ve Treitel, S., 1984. A review of leastsquares inversion and its application to geophysical problems, Geophysical Prospecting, 32, 2, 159-186.

Luke, S., 2009. Essentials of metaheuristics. Lulu, Retrieved January $20^{\text {th }}, 2012$, from http://cs.gmu.edu/ sean/book/ metaheuristics/.

Marquardt, D.W., 1963. An algorithm for least-squares estimation of nonlinear parameters, Journal of the Society for Industrial and Applied Mathematics, 11(2): 431-441.

McCulloch, W.S., ve Pitts, W., 1943. A logical calculus of the ideas immanent in nervous activity, Bulletin of Mathematical Biology, 5, 4, 115-133.

Oruç, B., 2010. Depth estimation of simple causative sources from gravity gradient tensor invariants and vertical component, Pure and Applied Geophysics, 167, 10, 1259-1272.

Oruç, B., 2012. Teori ve Örneklerle Jeofizikte Modelleme. Umuttepe Yayınları, Kocaeli.

Osman, O., Albora, A.M., ve Ucan O.N., 2007. Forward modeling with forced neural networks for gravity anomaly profile, Mathematical Geology, 39, 6, 593-605.

Poulton, M.M., Sternberg, B.K., ve Glass, C.E., 1992. Location of subsurface targets in geophysical data using neural networks, Geophysics, 57, 12, 1534- 1544.

Reid, A.B., Allsop, J.M., Granser, H., Millett, A.J., ve Somerton, I.W., 1990. Magnetic interpretation in three dimensions using
Euler deconvolution, Geophysics, 55, 1, 80-91.

Roest, W. R., Verhoef, J., ve Pilkington, M., 1992. Magnetic interpretation using 3-D analytic signal: Geophysics, 57, 116125.

Roth, G., ve Tarantola, A., 1994. Neural networks and inversion of seismic data, Journal of Geophysical Research, 99, B4, 6753-6768.

Roy, A., 1962. Ambiguity in geophysical interpretation, Geophysics, 27, 1, 90-99.

Roy, L., Agarwal, N.P., ve Shaw, R.K., 2000. A new concept in Euler deconvolution of isolated gravity anomalies, Geophysical Prospecting, 48, 3, 559-575.

Rumelhart, D.E., Hinton, G.E., ve Williams, R.J., 1986. Learning internal representation by error back propagation. In: D.E. Rumelhart and J.L. Mc Clelland (eds.), Parallel Distributed Processing: Explorations in the Microstructure of Cognition. Vol. 1. Foundations, MIT Press, Cambridge, USA, 318-362.

Salem, A., Elawadi, E., ve Ushijima, K., 2003. Short note: Depth determination from residual gravity anomaly data using a simple formula, Computer and Geoscience, 29, 6, 801-804.

Sen, M. K., ve Stoffa, P. L., 1991. Nonlinear multiparameter optimization using genetic algorithms: Inversion of plane wave seismograms, Geophysics, 56, 17941810.

Sen, M.K., ve Stoffa, P. L., 1992. Seismic waveform inversion using global optimization. Journal of Seismic Exploration, 1, 9-27.

Szu, H., ve Hartley, R., 1987. Fast Simulated Annealing, Physical Letters A, 122, No. 3, 157-162.

Thompson, D.T., 1982. EULDPH: A new technique for making computer-assisted depth estimates from magnetic data, Geophysics, 47, 1, 31-37.

Vestergaard, P. D., ve Mosegaard, K. 1991. Inversion of post-stack seismic data 
using simulated annealing, Geophysical Prospecting, 39, 613-624.

Wang, L.X., ve Mendel, J.M., 1992. Adaptive minimum prediction-error deconvolution and source wavelet estimation using Hopfield neural networks, Geophysics, $57,5,670-679$.
Zhang, Y., ve Paulson K.V., 1997. Magnetotelluric inversion using regularized Hopfield neural networks, Geophysical Prospecting, 45, 5, 725-743. 
